\title{
Development of the composition of cereal dishes of higher biological value
}

\author{
Elena Chernova $^{1 *}$, Irina Bazhenova $^{2}$, and Tatiana Bazhenova ${ }^{3}$ \\ ${ }^{1}$ Department of Hotel and Restaurant Business, Saint-Petersburg State University of Economics, St. \\ Petersburg, Russia \\ ${ }^{2}$ Graduate School of Biotechnology and Food Production, Peter the Great St. Petersburg Polytechnic \\ University, St. Petersburg, Russia \\ ${ }^{3}$ Institute of secondary vocational education. Peter the Great St. Petersburg Polytechnic University, St. \\ Petersburg, Russia
}

\begin{abstract}
Main food products of Russians are cereals, various meat and fish. The phenomenon of Russian and another national cuisines are balance of main nutrients in their dishes. Traditional Russian dishes are different kinds of porridge and culinary products made of cereals. Grits themselves are the source of protein, carbohydrates, lipids, fiber, vitamins of B group, biologically active substances and minerals but unbalanced grain protein in amino acid content is considered to be a serious deficiency. There is the lack of lysine, threonine, tryptophan in the majority of grains, so vegetable protein is digested and processed harder than animal protein. That is why, while developing compositions of dishes, it is necessary to consider availability and digestibility of the protein. Level of digestion of protein can be estimated during the process of digestion of food products by the system of ferments in vitro. In this work you can see the results of the research of amino acid composition of protein and their hydrolyzates after enzymatic hydrolysis in boiled grains. It can be seen that hydrolyzates have bigger coefficient of utilized protein and lower percentage of unutilized protein comparing with untreated grits. According to these results they developed two-, three-, four-component compositions from buckwheat, barley, oats and millet grains and elaborated more than 100 optimal compositions of dishes from grains.
\end{abstract}

\section{Introduction}

The population of the countries where food products are physically and economically available, now faces the problem of increasing number of overweight people during last decade. The fact is that this group of people suffers from poorer life quality and chronical diseases. Recommendation of moderation in eating and healthy diet has not been recognized as a trend recently. These principles can be seen in Christian approach to food diet with reasonable moderation in eating and their attempts to avoid running to extremes. Saint Maxim Confessor claims: "Gluttony but not food is evil" [1]. In Talmud you can find

\footnotetext{
* Corresponding author: chernova68@list.ru
} 
actual recommendations for having meal: "Slow eating will make your life longer... Fill one third of your stomach with food, another third with drink, leave the rest empty." "Those who grow their maw, will grow their illnesses... More people die from overeating than from starvation" [2]. In the book "Codex of convenances in the East" they recommend to take meals moderately, avoid surfeit and not to eat fully [3].

Healthy diet does not mean only regularity and moderation, consuming useful food products is also important. Nutrition should provide a human with nutrient materials and carry out prophylactic and therapeutic functions as well [4]. Kovalev N.I professor, Doctor of Science, Russian cuisine researcher believed that Russian national cuisine demonstrates compositions of dishes which possess wonderful taste and high nutritional value and balanced nutrient content [5]. Russian people like cereals which they prepare from oats, buckwheat, barley, millet and rice grains. Ancient Russian dish is kulesh- semifluid dish made from grains and cooked with different food products. Prefiguration of kulesh is different pottages which are named "kashitsa". In the "List of czarist dishes" (1610-1613) they mention mushrooms, cooked in kashitsa, sturgeon, pike perch, burbot kashitsa, chicken in noodles, hare in noodles which were specific soups, not a hot dish with garnish [6]. Main grit to prepare kashitsa was millet. Kulesh was a simple and easy to cook dish which was popular among common people [7].

Analyzes of historical sources reveals that main grains in the diet of the population of Russia were millet, oats and barley and during the Middle Ages buckwheat and rice gained their position in this list as well. The fact that Russians grew a lot of crops and used them as food products is approved by archeologic, ethnographic, historical records [8-13], chronicles [14-16], memories of travelers [17, 18], folk tales and stories [19, 20]. Plenty of research works are devoted to the usage of crops to manufacture healthy food products [2125 etc.]

Grains are providers of assimilable carbohydrates, fiber, vitamins of B group, minerals and the source of cheap vegetable protein [26-29]. However, grain protein suffers from the lack of essential amino acids- lysine, threonine, tryptophan. Optimization of ration and dish compositions in their amino acid content, rise of food and energetic value are based on principle of mutual protein enrichment of different food products.

Speaking about metabolism, only amino acids contained in digested part of protein and taken from gastro-intestinal tract can participate in metabolic process of protein synthesis. Traditionally you can estimate digestion of protein by model experiments on the process of digestion of food products by the system of ferments in vitro. During last year's different approaches how to estimate biological value of protein appeared [30]. Fermentation and germination increase the nutritional value of cereals [31-33], and the physical and chemical composition is influenced by the growing conditions and processing methods [34].

Aim of the research: to investigate amino acid composition of fermentative hydrolysates of grains and calculation of optimized compositions of grain dishes which provide higher biological value.

\section{Methods of research}

Object of the research: boiled buckwheat, barley, oats, millet grains and solid residual after their fermentative hydrolysis. Grains were boiled with standard atmosphere pressure and temperature of $100{ }^{\circ} \mathrm{C}$ without salt and liquid removal according to the following proportions of grain and water: buckwheat $1: 1.5$; barley $1: 2.4$; oats $1: 3.2$; millet $1: 1.8$.

Amino acid composition of protein was estimated by chromatographic method with automatic aminoaniline "Geol" (Japan). Hydrolysis of protein was implemented by $6 \mathrm{~h} \mathrm{HCl}$ with the temperature of $110{ }^{\circ} \mathrm{C}$ in atmosphere of nitrogen during $24 \mathrm{~h}$, using $\beta$ - 
mercaptoethanol and $\beta$-thiodiglycol to prevent destruction of sulfur amino acids (methionine, cysteine).

The research of digestibility of boiled grains was implemented with laboratory fermenter "Vibrotherm" E-204/2 (Hungary) and they used analogue of pronase, enzymatic preparation which contains group of proteases produced by micro-organisms Aspergillus oryzae that are characterized by endopeptidase and exopeptidase activity with $\mathrm{pH}$ 6.3-6.5 and temperature of $37^{\circ} \mathrm{C}$, the time of hydrolysis is $24 \mathrm{~h}$.

Protein balance was estimated by the score of essential amino acids. Biological value (protein utilization coefficient) was estimated according to the calculation method of Kovalev N.N. and Kartseva N.J. [35]. Calculation of optimized mixtures and compositions of dishes was implemented by the computer program LIS "Optimization of amino acid composition". Mathematical processing of results was fulfilled by least square method with confidence level of probability 0.95 .

\section{Research results}

Research indicates that the highest digestibility of protein belongs to buckwheat and barley grits $(71.71 \%$ and $70.00 \%$ respectively), for millet and oats grains it is $47.33 \%$ and 37.22 $\%$ respectively.

Obtained experimental results on amino acid composition of boiled grain protein approve experimental evidence which was published by another authors [36 and etc.], containing minor differences in estimation of the content of aspartic acid and alanine in buckwheat; proline, methionine, tyrosine in oats grain; glutamic acid, proline in barley; histidine, proline, tyrosine in millet grit. All these differences can be explained by the dependence of amino acid content of crops and grains from growing condition and varietal features.

According to the results of the analyzes of amino acid content of protein in boiled grains and their solid residual after fermentative hydrolysis, they calculated the content of amino acids in grain hydrolysate. Results on the content of essential amino acids are represented in Table 1.

Table 1. Amount of essential amino acids of boiled grain protein and their fermentative hydrolysates.

\begin{tabular}{|c|c|c|}
\hline \multirow{2}{*}{ Cereals } & \multicolumn{2}{|c|}{ Amount of essential amino acids, mg/gr of protein } \\
\cline { 2 - 3 } & boiled grains & hydrolysate \\
\hline Buckwheat & 353,7 & 332,0 \\
\hline Barley & 301,2 & 300,0 \\
\hline Oats & 320,6 & 298,0 \\
\hline Millet & 363,9 & 367,0 \\
\hline
\end{tabular}

It is clear from the table that the amount of essential amino acids in proteins of boiled grains and their hydrolysates is different. It can be explained by the difference in degree and depth of hydrolysis. It is interesting that amino acid scores are different for these objects of the research (Table 2).

In our opinion, it is necessary to consider content and proportion of amino acids only in hydrolyzed part of the protein when you calculate biological value of grain protein for optimization of compositions of dishes.

Optimal compositions are those which possess higher biological value and their amino acid content approaches standard value of protein recommended by WHO. According to the method of Kovalev and Kartseva, the criteria for optimal proportion of products is achievement of the highest value of the coefficient of the utilization of protein (CUP) and the smallest proportion of unutilized protein $(\Delta \mathrm{P})$. During this research compositions of 
two-, three-, four-component mixtures of grains were optimized, the following mixtures were investigated: buckwheat + barley (1), buckwheat + oats (2), barley + oats (3), oats + millet (4), buckwheat + barley + millet (5), barley + oats + millet (6), buckwheat + barley + oats $(7)$, buckwheat + oats + millet $(8)$, buckwheat + barley + oats + millet $(9)$. Results are represented in Tables 3, 4 .

Table 2. Scores of essential amino acids of boiled grains and their fermentative hydrolysates.

\begin{tabular}{|c|c|c|c|c|c|c|c|c|}
\hline \multirow[b]{2}{*}{$\begin{array}{c}\text { Essential amino } \\
\text { acid }\end{array}$} & \multicolumn{2}{|c|}{ Buckwheat } & \multicolumn{2}{|c|}{ Barley } & \multicolumn{2}{|c|}{ Oats } & \multicolumn{2}{|c|}{ Millet } \\
\hline & 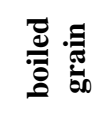 & 它 & 施 & 主苞 & 窇 & 完 & 窇 & 它 \\
\hline Lys & 117,7 & 139,9 & 62,8 & 56,4 & 74,4 & 78,2 & 39,2 & 34,6 \\
\hline Thre & 85,8 & 85,0 & 81,4 & 84,9 & 81,4 & 87,5 & 65,4 & 39,7 \\
\hline Val & 124,3 & 121,8 & 100,5 & 99,9 & 117,7 & 107,9 & 105,5 & 66,2 \\
\hline Isoleu & 92,6 & 65,0 & 109,2 & 110,0 & 103,1 & 90,0 & 169,1 & 230,2 \\
\hline Leu & 101,1 & 85,7 & 93,7 & 98,7 & 111,8 & 120,0 & 162,1 & 218,5 \\
\hline Met+ Cys & 38,0 & 37,1 & 10,0 & 14,1 & 18,4 & 20,0 & 41,6 & 48,4 \\
\hline Phen + Tyr & 117,5 & 103,4 & 115,0 & 145,0 & 103,9 & 65,1 & 113,0 & 61,7 \\
\hline
\end{tabular}

Table 3. Optimization of grain compositions on amino acid content of proteins of boiled grains.

\begin{tabular}{|c|c|c|c|c|c|}
\hline $\begin{array}{l}\text { Mixture } \\
\text { of grains }\end{array}$ & $\begin{array}{c}\text { Optimized } \\
\text { proportion \% }\end{array}$ & $\Delta \mathrm{P}, \mathrm{mg} / \mathrm{gr}$ & $\begin{array}{l}\text { Limiting amino } \\
\text { acid score }\end{array}$ & CUP, & $\begin{array}{l}\text { Limiting } \\
\text { amino acid }\end{array}$ \\
\hline 1 & $\begin{array}{l}27.80: \\
72.20\end{array}$ & 55.59 & 0.80 & 65.18 & Lys \\
\hline 2 & $\begin{array}{l}\text { 15.80: } \\
84.20\end{array}$ & 64.05 & 0.80 & 46.21 & Thre \\
\hline 3 & $\begin{array}{l}\text { 11.57: } \\
88.43\end{array}$ & 85.61 & 0.71 & 41.13 & Met+ Cys \\
\hline 4 & $\begin{array}{c}95.49: \\
4.51 \\
\end{array}$ & 88.13 & 0.71 & 37.88 & Met+ Cys \\
\hline 5 & $\begin{array}{c}\text { 15.17: } \\
83.53: \\
1.30\end{array}$ & 64.64 & 0.79 & 45.89 & Thre \\
\hline 6 & $\begin{array}{c}\text { 9.35: } \\
89.78: \\
0.87\end{array}$ & 86.09 & 0.71 & 40.51 & Lys \\
\hline 7 & $\begin{array}{c}27.80: \\
72.17: \\
0.03\end{array}$ & 55.59 & 0.80 & 65.18 & Lys \\
\hline 8 & $\begin{array}{c}\text { 27.78: } \\
71.45: \\
0.77\end{array}$ & 56.13 & 0.80 & 64.98 & Thre \\
\hline 9 & $\begin{array}{c}22.36: \\
45.60: \\
31.10: \\
0.94\end{array}$ & 58.78 & 0.80 & 58.19 & Thre \\
\hline
\end{tabular}


Table 4. Optimization of grain compositions on amino acid content of proteins of hydrolysates of grains.

\begin{tabular}{|c|c|c|c|c|c|}
\hline $\begin{array}{c}\text { Mixture of } \\
\text { grains }\end{array}$ & $\begin{array}{c}\text { Optimized } \\
\text { proportion, } \%\end{array}$ & $\Delta \mathrm{P}, \mathrm{mg} / \mathrm{gr}$ & $\begin{array}{l}\text { Limiting amino } \\
\text { acid score }\end{array}$ & CUP, & $\begin{array}{l}\text { Limiting } \\
\text { amino acid }\end{array}$ \\
\hline 1 & $\begin{array}{c}25.54: \\
74.46\end{array}$ & 39.30 & 0.82 & 96.07 & Thre \\
\hline 2 & $\begin{array}{l}32.23: \\
67.77\end{array}$ & 54.53 & 0.70 & 94.55 & Isoleu \\
\hline 3 & $\begin{array}{l}80.22: \\
19.78\end{array}$ & 80.37 & 0.76 & 91.96 & Thre \\
\hline 4 & $\begin{array}{l}\text { 18.02: } \\
81.98\end{array}$ & 56.70 & 0.63 & 94.33 & Meth+ Cys \\
\hline 5 & $\begin{array}{c}\text { 42.11: } \\
48.78: \\
9.11\end{array}$ & 50.37 & 0.75 & 94.96 & Isoleu \\
\hline 6 & $\begin{array}{c}18.42: \\
80.37: \\
1.21\end{array}$ & 56.62 & 0.63 & 94.34 & Phen+ Tyr \\
\hline 7 & $\begin{array}{c}22.57: \\
25.02: \\
52.41\end{array}$ & 30.44 & 0.77 & 96.96 & Meth+ Cys \\
\hline 8 & $\begin{array}{c}25.35: \\
73.81: \\
0.84\end{array}$ & 40.30 & 0.82 & 95.97 & Lys \\
\hline 9 & $\begin{array}{c}\text { 21.63: } \\
\text { 40.92: } \\
37.01: \\
0.44\end{array}$ & 32.64 & 0.78 & 96.74 & Thre \\
\hline
\end{tabular}

Obtained results for two-component mixtures of grains demonstrate that it is impossible to optimize mixtures of barley + millet and buckwheat + millet which were calculated on amino acid content of protein in boiled grains; the same situation is true for mixtures of barley + millet and oats + millet, calculated on amino acid content of hydrolysates. It can be explained by the fact that protein of these grains contains similar first and second limiting amino acids.

Obtained results of calculated biological value of amino acid content of boiled grains and their hydrolysates differ from each other in most cases; CUP of optimal mixtures calculated on amino acid content of protein of hydrolysates is higher than results of calculation for proteins of original grains for mixture buckwheat + barley on $30.89 \%$, buckwheat + oats on $48.34 \%$, barley+ oats on $53.20 \%$. Meanwhile, for mixture buckwheat + barley for both variants of calculations, optimal proportion of products is almost similar and for mixture buckwheat + oats fluctuations are significant.

For all mixtures biological value calculated on amino acid content of hydrolysates is considerably higher than results calculated on protein content of grains (CUP -1.8 times higher; proportion of unutilized protein $(\Delta \mathrm{P})$ - 1.2 times lower).

Obtained results have become the basis of development of composition of dishes from grains. 


\section{Discussion}

In this research they suggest the approach how to estimate biological value of proteins of grain dishes by amino acid content of grain hydrolysates, without noticing main content of amino acids in raw or cooked products. It was established experimentally that boiled grains and their fermented hydrolysates considerably differ in amino acid content of protein, utilized and unutilized parts of protein.

Grains which are used in Russian cuisine are the source of protein, carbohydrates, lipids, fiber, vitamins of B group, biologically active substances and minerals. Since grain protein is unbalanced in some essential amino acids, utilization of the protein is decreasing. That is why it is expedient to optimize some grain dishes in their amino acid content. Intuitively, during long history of development Russian dishes have become balanced in main nutrients. Adding fish, meat, milky products to grain dishes increases their biological value and digestibility.

Obtained results for biological value of two-component mixtures of grains show that it is higher for those which were optimized on amino acid content of protein of hydrolysates. According to calculations, proportion of buckwheat in the mixture with barley can fluctuate from 25 to $47 \%$, in its mixture with oats it fluctuates from 25 to $40 \%$. In the mixture of buckwheat and millet the proportion of buckwheat can range from 65 to $85 \%$. The proportion of barley in its mixture with oats can fluctuate from 15 to $25 \%$. Changes of proportions in stated limits do not practically influence on variation of the coefficient of the utilization of protein (CUP).

Three component mixtures showed the same regularities. The usage of millet there do not increase biological value of the mixture and it is inexpedient to apply it. The strongest effect of mutual enrichment is registered in the mixture of buckwheat + barley + oats where CUP is equal to $96.96 \%$. Four-component mixtures can be used for the expansion of the assortment of dishes and organoleptic enhancement. CUP is increasing in the following range: one grain dish $<$ dish from two-component grain mixture $<$ dish from threecomponent grain mixture, for dishes from four-component grain mixtures CUP stops increasing.

Considerable increasing of CUP and decreasing of $\Delta \mathrm{P}$ of multi-component grain mixtures in comparison to single grain allow to develop different compositions of tasty and healthy dishes from grains. Authors worked out more than 100 compositions of dishes and grain culinary products: porridge without filling, porridge from grain mixtures flavored with pumpkin, prunes, carrot, apples, raisins; krupeniks, casserole with pumpkin and fresh fruits, cue balls and carrot balls, kulesh with meat; porridge with fish, minced fish with grains. It is interesting that utilization of protein is $10 \%$ higher in developed compositions of dishes, comparing to traditional compositions of the same dishes.

Conducted research allows to prove scientifically the usage of hydrolyzed grain mixtures. Two- and three-component grain mixtures, prepared in optimal proportions, increase utilization and digestion of protein comparing to traditional compositions. Practical significance of this research is assortment expansion of Russian grain dishes with high biological value.

\section{References}

1. Maksim Ispovednik. URL: http://sp-g.ru/?p=303

2. Flavian Bren'e. Evrei i Talmud. URL: http://lib.ru/POLITOLOG/AE/brenie.htm. 
3. Muhammed Sadyk Kashgari. Kodeks prilichij na Vostoke (Adab-ul'-salihyn).

Muhammed Sadyk Kashgari. Kodeks prilichij na Vostoke (Adab-ul'-salihyn). URL: https://rusneb.ru/catalog/000199_000009_008357330/.

4. E. Chernova, I. Bazhenova, T. Bazhenova, 5th International Conference «Arctic: History and Modernity». Conf. Series: Earth and Environmental Science 539 (2020).

5. N.I. Kovalev, Russkie narodnye blyuda, ih pishchevaya cennost' i puti ee povysheniya, Leningrad, 1989.

6. Rospis' carskim kushan'yam. Akty istoricheskie, sobrannye i izdannye geograficheskoyu komissiej. T. 2. URL:

https://runivers.ru/bookreader/book457133/\#page/436/mode/1up.

7. N. Kovalev, E. Zachinyaeva, Pitanie i obshchestvo, 4 (1996).

8. V.V. Latyshev, Izvestiya drevnih pisatelej grecheskih i latinskih o Skifii i Kavkaze. Tom 1. Grecheskie pisateli, Vypusk 1, Sankt-Peterburg (1893).

9. V.I. Dovzhenok, K istorii zemledeliya u vostochnyh slavyan v I tysyacheletii n.e. i v epohu kievskoj Rusi, Moskva (1952).

10. V.V. Hvojko, Nachalo zemledeliya i bronzovyj vek v Srednem Pridnestrov'e, Moskva (1907).

11. P.N. Tret'yakov, Sel'skoe hozyajstvo i promysly // Istoriya kul'tury Drevnej Rusi. T.1: Domongol'skij period; Material'naya kul'tura, Moskva, Leningrad (1948).

12. B.D. Grekov, Krest'yane na Rusi s drevnejshih vremen do XVII veka, Moskva (1952).

13. N.I. Kostomarov, Ocherk domashnej zhizni i nravov velikorusskogo naroda v XVIXVII stoletiyah, Moskva (1992).

14. Domostroj, Sankt-Peterburg (1992).

15. Novgorodskie piscovye knigi, izdannye Arheologicheskoyu Komissieyu. T.3. Perepisnaya obrochnaya kniga Votskoj pyatiny, 1500 goda. Perv,aya polovina, SanktPeterburg (1868).

16. Polnoe sobranie russkih letopisej. Vyp. 1: Povest' Vremennyh Let, Leningrad (1926).

17. S.G. Gmelin, Puteshestvie po Rossii dlya issledovaniya trekh carstv prirody: Per. s nem. Ch. 2. Puteshestvie ot Cherkaska do Astrahani i prebyvanie v sem gorode: $\mathrm{s}$ nachala avgusta 1769 po 5-e iyunya 1770 goda, Sankt-Peterburg (1777).

18. I. Lepekhin, Dnevnye zapiski puteshestviya doktora i akademika nauk ad"yunkta Ivana Lepekhina po raznym provinciyam Rossijskogo Gosudarstva, 1768 i 1769 godu. Ch. 1, (Sankt-Peterburg (1795).

19. Russkie drevnie svad'by. Skazaniya russkogo naroda, sobrannye N. Saharovym, SanktPeterburg (1849).

20. Russkij narod, ego obychai, obryady, predaniya, sueveriya i poeziya. Sobr. M. Zabylinym, Moskva (1990).

21. T.S. Bazhenova, I.A. Bazhenova, XI Rossijskij forum s mezhdunarodnym uchastiem «Zdorovoe pitanie s rozhdeniya: medicina, obrazovanie, pishchevye tekhnologii», 1315 (2016).

22. I.A. Bazhenova, T.S. Bazhenova, E.V. Chernova, Agronomy Research, 17, 6 (2019).

23. I. Joye, Foods, 8, 6 (2019).

24. K. Zhang, J. Sun, M. Fan, H. Qian, H. Ying, Y. Li, L. Wang, Trends in Food Science \& Technology, 109 513-526 (2021).

25. R.P. F.Guinéa, S.G. Florençab, M.J. Barrocac, O. Anjosde, Trends in Food Science \& Technology, 109, 16-24 (2021). 
26. B.A. Williams, D. Mikkelsen, B.M. Flanagan, M.J. Gidley, J. of Animal Sci and Biotechnology, 10, 45 (2019).

27. M.G. Ferruzzi, J. Kruger, Z. Mohamedshah, H. Debelo, John R.N.Taylor, J. of Cereal Science, 96, 103126 (2020).

28. K. Christa, M. Soral-Śmietana, Czech J. Food Sci., 26 (2008).

29. F. Zhu, Trends in Food Science \& Technology, 110, 155-167 (2021).

30. C.P.F. Marinangeli, J.D. House, Nutr. Rev, 75, 8 (2017).

31. S.G. Nkhata, E. Ayua, E.H. Kamau, J.-B. Shingiro, Food Science \& Nutrition, 6, 8 (2018).

32. E. Lemmens, A.V. Moroni, J. Pagand, P. Heirbaut, A. Ritala, Y. Karlen, K.-A. Lê, H.C. Van den Broeck, Fred J.P.H. Brouns, N. De Brier, J.A. Delcour, Comprehensive Reviews in Food Science and Food Safety, 18, 1 (2019).

33. P. Tsafrakidou, A.-M. Michaelidou, C.G. Biliaderis, Foods, 9, 6 (2020).

34. S. Kavitha, R. Parimalavalli, J. Hum, Nutr. Food Sci, 2, 6 (2014).

35. N.I. Kovalev, N.YA. Karceva, V.O. Fiterer, Voprosy pitaniya, 2 (1989).

36. S.A. Konov, Biologicheskie osnovy sovremennoj agronomii: sb. materialov nauch.praktich. konf., 38, 72-76 Orel (2004). 